\title{
Artigo
}

\section{Shortcomings of global multilateral agrifood trade and a new food- dependency-based protagonism}

Insuficiências do comércio agroalimentar multilateral global e um novo protagonismo baseado na dependência alimentar

DOI: 10.5752/P.1809-6182.2016v13.n2.p94

Ricardo César Barbosa Júnior ${ }^{1}$

Matheus Hoffmann Pfrimer ${ }^{2}$

Recebido em: 30 de março de 2016

RESUMO

Aprovado em: 22 de julho de 2016

Nesse artigo, exploramos a relaçâo entre a agricultura e a liberalização do comércio, discutindo a postura dissidente dos Paises de Alta Renda com Dependência Alimentar (PAR$D A)$ em um cenário após a crise de alimentos de 2008. Indicando como essas mudanças levaram a emergência de um novo protagonismo baseado na dependência alimentar na qual a segurança possui primazia sobre o comércio.

Palavras-Chave: Organização Mundial do Comercio (OMC); agricultura; países de alta de renda com dependência alimentar (PARDA)..

\section{ABSTRACT}

In this paper, we explore the relationship between agriculture and trade liberalisation, by discussing the dissident posture of high-income food-dependent countries (HIFDC) in the post 2008 food crises scenario. Indicating how these changes have led to the emergence of a new food-dependency-based protagonism where security has primacy over trade.

Key words: Word Trade Organisation (WTO); agriculture; high-income food-dependent countries (HIFDC).

1. Undergraduate student of International Relations, at the Federal University of Goiás, and Law, at the Pontifical Catholic University of Goiás. Currently he is a Research Assistant at the Center for Global Studies (NEG). Contact: ribarbosajr@gmail.com. orcid.org/0000-0002-2704-3110

2. BA in Law, from the Catholic University of Goiás, and Geography, from the Federal University of Goiás. Has a MA in International Relations and European Integration from Liège University in Belgium, a Ph.D. and Post-doctorate in Political Geography from the University of São Paulo. Currently he is professor of Geopolitics and Security Studies at Federal University of Goiás' International Relations program. Contact: matheuspfrimer@hotmail.com. orcid.org/0000-0003-3472-3314 


\section{Introduction}

When it comes to agriculture the World Trade Organisation (WTO) and its free trade regime has proved to be inadequate (BURNETT, 2015) as food is different from other internationally traded goods. Traditionally, critics are based upon power asymmetries that occur both within the institution and as a result of the changes its policies imposes upon the countryside (DESMARAIS 2007). These are generally framed through political discourses, under the food sovereignty flag, with the objective of promoting a shift in global power relations (BARBOSA JÚNIOR; COCA, 2015b). Less verbal and more pragmatically, however, are the initiatives of high-income food-dependent countries (HIFDC) that have since the 2008 food crisis (MARGULIS, 2009) started to seek alternatives to the multilateral international food trade system. This dissidence is unlike the opposition traditionally offered by the least developed countries ${ }^{3}$ (LDCs) and social movements, for while HIFDC are not formally splitting from the WTO their practices demonstrate a tacit renouncement of its multilateral free trade structure.

In this paper, we seek to:

- identify these countries and conceptually characterise them;

- discuss their motivations and modus operandi generally;

- in order to demonstrate how a new food-dependency-based protagonism is taking form. Thus, our analysis will focus on interstate relations and their contentious disputes in what we characterise as a new food-dependency-based protagonism.

\footnotetext{
3. While least developed countries offer a state-based resistance to the WTO, their focus is mostly directed towards the undemocratic nature of its decision making process. Thus, rather than altogether forgoing the institution there aim remains largely in reforming it.
}

In addition to this introduction and final considerations, we divide this work into three parts. First, we explore the different motivations that exist within the international multilateral agrifood trade system. Then we characterise HIFDC and discuss their responses to the 2008 food crisis, comprehending their posture as recalcitrant. Lastly, we attempt to conceptualise this process as a whole describing these initiatives as indicating the establishment of a new food-dependency-based protagonism, debating what this means for the WTO.

\section{Food trade between profit and security}

Not all countries engaged in international food trade seek profit. For, while many do export and import agricultural goods as a means of increasing their Gross Domestic Product (GDP), this is not altogether the case. Generally, within the model of neoliberal international free trade there are in one hand countries that export food, disposing of elements that allow them better comparative advantages. For instance, accessible labor, arable land, water, and technology, among other factors. On the other hand, within the same logic, there are those who choose to import food focusing their efforts on more profitable ventures, as food production would be less economical. In addition, a select group of countries depend on food-imports in a way that is more vital than those last. These countries are unable to produce enough food to satisfy its population's necessity, as even if they chose to do so they would be incapable, for they lack one or more of the elements essential for agriculture. Due to this, it is imperative to draw a distinction between food-importing countries that articulate within the international agrifood market.

In this work, we will give emphasis to the group of countries that trade as a form to pro- 
mote national food security. While it may appear to be counter intuitive, not all food-importing countries are wealthy. For instance, many of the LDCs also hold a negative agrifood trade balance (see Map 01) as even if they possess the natural elements for agriculture - labor, land and water - they are still limited do to aspects such as infrastructure, political stability, and access to technology ${ }^{4}$ (MURPHY, 2015; RAKOTOARISOA et al. , 2012; WISE, 2015). This creates a subsequent distinction between low-income food-dependent countries (LIFDC) and high-income food-dependent countries (HIFDC), in our analysis we focus on the latter. It is essential to draw attention to this peculiarity, as it helps to clarify why the reactions from these two types of food-deficit countries to the 2008 food crisis are distinct. While they all have begun to take alternative measures as a response, these are different largely due to their income.

It is also crucial to recognise that even if a country is not in the situation of food insecurity, this does not mean that it is plainly food secure. That is, a country that relies mostly on its own natural conditions for agriculture could largely self-sustain, up-

\footnotetext{
4. It is important to note that the type of technology makes all the difference. For instance, even if some technologies were introduced, it would demand great efforts to maintain production, as they are also extremely costly. A classic example is Pioneer's technological packages that join seeds, fertilisers and pesticides. Introducing machinery would also have a high initial cost, and in either cases, these changes could very well lead to greater food insecurity even if production was higher. Historically, this can be evidenced through the 1990s when many of these countries were instructed by the International Monetary Fund (IMF) and the World Bank to abandon subsistence farming and focus on agricultural exports, giving priority to a commercial balance, in turn, making them dependent on imports of staple foods, as they became exporters of tropical goods and cotton. This is especially concerning as, in LDCs most of the income comes from agriculture, while at the same time most of the food comes from subsistence farming. If the technology deployed eliminates jobs or promotes land concentration, then there will be less wages and crops for food. Thus rather than just referencing the best available technology, we also draw attention to the technique. There are many cases where the technique, that is, the application of a method, generates more results than technology, referencing the instrument to be handled by a type of technique.
}

holding more independently its food security. While, for the others this is only possible by means of international trade. These countries are in a constant food security dependency, and for them the distrust in the international market is much more severe.

There are different forms of dependency, perhaps there is no better form of dependency, but there are those that bring about more urgency. The very concept of complex interdependency is based upon the principle of mutual dependency and possibility of mutual gain - where countries would cooperate because any struggle would be too costly and thus not rational (KEOHANE; NYE, 1977). This notion does hold some significance, e.g. developing countries rely on developed countries technology to "modernise" their processes and even developed countries depend on developing countries' consumer markets for their output production. Nevertheless, these are not equivalent, in proportion, to the need of satisfying a population's biological metabolism. For in this case the choice is simple, trade or perish.

The international food trade calamity - and its inability to provide supply, access, variety and nutrition - led food-importing countries to doubt that the international multilateral trade system could be liable for upholding food security (MARGULIS, 2014a). While to some extent both LIFDC and HIFDC look inward to promote policies that would make them less dependent on food-imports, HIFDC have also began to take other interventionist measures, that can, to an extent, even be characterised as imperialist (AMIN, 2012).

\section{HIFDC and their responses to the food crises}

As with other matters of high politics, we argue that it is possible to identify a course where food security takes supremacy over trade liberalisation. 


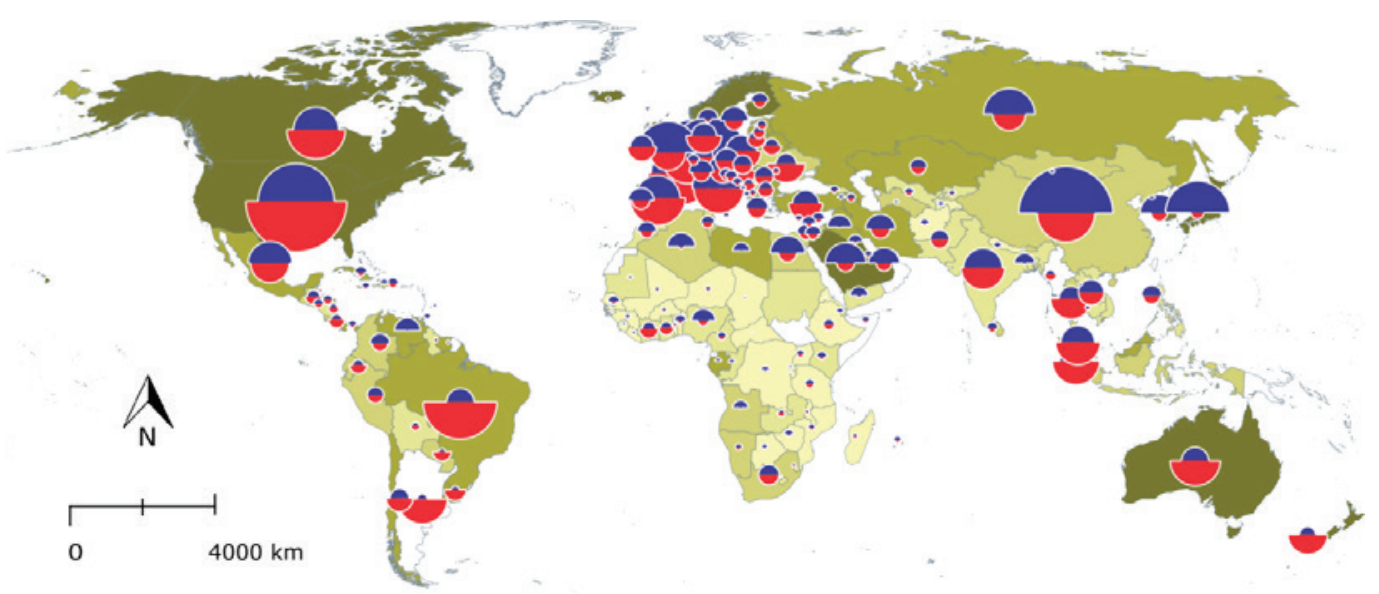

Global agrifood trade balance and GDP per capita by country (2014)
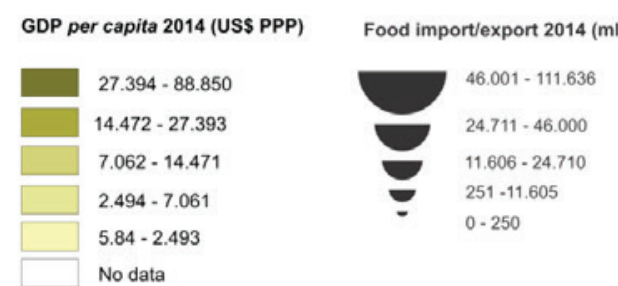

Source: Organised by Barbosa Júnior and Pfrimer (2016).

HIFDC have begun to promote unilateral, bilateral and plurilateral practices to satisfy this agenda. With the goal of assuring their food security, under the eminence of the global food market fallibility. These dissident postures are symptomatic of the structural problems intrinsic to international multilateral trade. Drawing attention to this can help to both, reconsider how the WTO`s stance on agrifood trade is operationally botched for more than LDCs, in addition to supporting the initiatives to either reform or all together forgo the WTO and its flawed regime.

In order to identify HIFDC we established the flowing parameters:

- low arable land (or arable land to population ratio) and/or low water (or water to population ratio);

- high capital and/or high technology; in addition to

- a negative agrifood trade balance'.

5. It is essential to highlight the distinction between food and
Based on the United Nations Food and Agriculture Organisation's (FAO) Statistical Pocketbook - World Food and Agriculture 2015, we projected GDP per capita (characterised by the shades of greens within the countries territorial borders) and the proportions of food export (top semi-circle in red) and import (bottom semi-circle in blue) in on Map 01. The countries where the two semicircles line up to form a circle, import and export agrifoods in similar dimensions. While those that do not, engage more in one in relation to the other.

First, it is possible to compare proportionately which countries are more and less invested in

other agricultural goods. As many agricultural outputs are not used for food such as cotton and other fibers, as well as oils that can used for a diversity of industrial goals, fuels, or animal feed. For our purposes we identify food as comprising "[...] the commodities in SITC sections 0 (food and live animals), 1 (beverages and tobacco), and 4 (animal and vegetable oils and fats) and SITC division 22 (oil seeds, oil nuts, and oil kernels)" (FAO 2015, p.227). Thus, a more appropriate term is agrifoods as a way to exclude fibers such as cotton, but demonstrating that not all food imports are destined for the purpose of direct human consumption. As an example, we highlight the import of oil seeds intended for the animal feed. 
international agrifood trade and in what capacity. Via analysing the size of the circles and the proportions of the semicircles that compose them. It is also possible to ascertain a country's agrifood trade balance, that is, whether it is importing or exporting more agrifoods and in what ratio comparatively. Through associating this information with the GDP per capita, the distinction between LIFDC and HIFDC becomes evident. Specifically, the HIFDC within our established categories are Saudi Arabia, United Emirate States, China ${ }^{6}$, South Korea and Japan.

Unilaterally, HIFDC have begun to be directed policy towards the increase of food self-sufficiency, an illustrative example of this is Japan (BURNETT 2015). Internationally, however, these countries have become engaged in global land grab as an attempt to grow food overseas (MARGULIS et al., 2013). McMichael (2013) characterises this practice as a new security mercantilism.

Bilaterally, these same states have begun to approximate and establish free trade agreements (FTAs) directly with food producing countries, e.g. South Korea ${ }^{8}$ has FTAs ${ }^{9}$ with India (2010), Peru (2011), United States (US) (2012), Colombia (2013), Turkey (2013), Australia (2014) Vietnam (2015), New Zealand (2015) and Canada (2015); in addition to having FTAs under negotiation with Mexico and Indonesia (Ministry of Foreign Affairs

6. Even though China does not have a high GDP per capita, it was identified as a HIFDC. The country's colossal population distorts this ratio even while it holds the second largest GDP in the world. In addition to the fact that it fits into all other established criteria and are promulgating similar policies and postures as other countries identified.

7. See World Land Grab (2016).

8. South Korea is a country that has a protectionist posture when it comes to its agriculture. Yet, due to the proportions its population has reached and its limited amount of agricultural resources; FTAs can be identified as a strategy of accessing food supplies. Paradoxically, while this country access foreign agrifood markets it faces enormous difficulties to open its own agricultural market.

9. Information updated with data from the Asia Regional Integration Center (2008).
Republic of Korea (2013). Plurilateraly, of most note is the Trans-Pacific Partnership (TPP) with Japan as a participating country along with discussions of South Korea becoming a partner (MINISTRY OF FOREIGN AFFAIRS REPUBLIC OF KOREA, 2013).

These measures showcase a modus operandi that is not only in disaccord with the principles of the WTO but as we understand it, also symptomatic of its limits. For they occur as a form to promote that which the international institutional cannot. Thus we are left with questions such as, what can be done about the WTO and how can this process as a whole be understood?

\section{The WTO and the new food-dependency-based protagonism}

There are those who defend changes through the WTO, indicating how developing countries have been key in promoting policies and decisions that favor food security (BURNETT; MURPHY, 2014). This view is not consensus, however, as the belief that even reform within the WTO would give legitimacy to its neoliberal agenda is also prevalent (DESMARAIS, 2015). These understand food sovereignty and local food systems as a more socially just and environmentally friendly alternative (BARBOSA JÚNIOR; COCA, 2015b; WITTMAN et al., 2010).

The first perspective defends that while the institution has its shortcomings it still has a large role to play in the promotion of food security (MURPHY 2015; KRIPKE 2015). For bilateral and even plurilateral trade and investment agreements that forgo the WTO leave out LDCs who no longer have the ability to articulate as a coalition, losing their agency and becoming unable to promote more inclusive conditions. While the critics of this 
view, believe that the WTO is in place primarily to give legitimacy to the demands of the Global North through the disparity in its decision making process (HOPEWELL, 2013) and the normative basis for dispute resolution (SOUZA, 2015). To them the WTO acts as one the Global North's governing institutions, and thus reform is a rhetoric more than an actual possibility.

The dissidence of HIFDC can be seen as a form of contesting the globalisation process that was pushed forth by the neoliberal economic restructuring, even if this is not their objective. For it questions the WTO regulated multilateral trade system that favors economic powers such as the US and European Union (EU). Nevertheless, there is need to further consider this development, for the disparity in capacity of actors in the international scenario might, in turn, make it so that LDCs suffer even greater food insecurity and are placed under more social, environmental and economic duress.

For those who defend this position, while the WTO does institute many structural mechanisms that perpetuate inequality, it provides a platform where the power dynamics are played out in a manner that permits the rise of countries such as Brazil and India who articulate with others to challenge the traditional dominance of the established powers (HOPEWELL, 2014; HURRELL; NARLIKAR, 2006). This leadership, as Hopewell (2013) stresses, does not challenge the WTO's neoliberal agenda, and despite all the detrimental consequences of its export-oriented agribusiness sector (BARBOSA JÚNIOR; COCA 2015A; BLESH; WITTMAN, 2015; CLEMENTS; FERNANDES 2013; PFRIMER; BARBOSA JÚNIOR, 2016). Brazil remains one of the most vocal advocates of the free market globalisation and pushes to expand liberalised global markets.

Regardless of what is the best path to be tak- en towards reform, there is a clear division within the international agrifood market between what is traded to promote food security and the general commodity and biofuels trade. The new protagonism ${ }^{10}$ of HIFDC does not follow the traditional North-South divide between countries, for some of those that would typically be understood as belonging to the South have started to conduct forms of sub imperialism, this in turn leads to a new spatiality of power (MARGULIS, 2014b). Furthermore, there is also the effect that this has on national and international trade policies, agricultural models and consumer patterns (POPKIN, 2006).

Based upon the research here depicted we understand this process as more than the just totality of its parts, composing what we conceptualise as a new food-dependency-based protagonism. Unlike social movements that contest the WTO openly, demanding, and even in some cases offering, an alternative model, the practices of HIFDC are still oriented by neoliberal principles. With the additional augment, of being conducted in a self-centred way that is even more destructive than the WTO's multilateral free trade regime. Thus, we characterise this process, demonstrating that the quest for individual solutions that forgo the WTO is a relapse to a course of traditional expression of power that is even more perilous than the flawed system they are breaking from.

10. The concern over food import dependency is not a new one. After the Second World War, the recently constructed EU established conditions to remain self-sufficient. The same took place within the Soviet Union that also had a logic of food supply that was not market based. However, since initiatives such as these, a multilateral trade platform was established that invited countries to opt in with the promise of satisfying their demands. With this not taking place, when it comes to food some countries are abandoning this order, especially the food-dependent with material means to do so. These states are now free riding, not only putting in place protectionist measures but also, interfering within other states. 


\section{Final considerations}

The progression here described configures a new power dynamic where food trade, in part, conditions some countries' national security. The 2008 food crisis was one of confidence (MURPHY 2015) for it undermined the premise of certainty. Despite the previous notion that global food production and trade is more stable than the attempts of states independently. Ultimately, it provided a transition from a matter that was of international political economy to one of national security. Within the context of power relations delimited by the international commerce of agrifood products.

We are not underestimating the struggle of LDCs, LIFDC or social movements in resisting the WTO by not focussing on them, but while the literature on these are extensive, the analysis of HIFDC might offer us a promising diagnosis of what ails global food trade, though another perspective. There is also great need for studies that focus upon the consequences of the initiatives carried by HIFDC.

While the market in multilateral free trade has not positioned itself as the best alternative for the promotion of food security, as became clear after 2008, to some extent the WTO has provided a platform for less discrepant trade relations. Thus, whether through the institution's reform or by means of an alternative venue, there is need for concern over HIFDC's rogue postures. Where through the pursuit of their security concerns, without mind to the costs and risks, are promoting social injustice and environmental unsustainability similar to what established powers carry out via the WTO.

\section{References}

AMIN, Samir. Contemporary Imperialism and the agrarian question. Agrarian South: Journal of Political Economy, v.1, n.1, p.11-26, 2012.

ASIA REGIONAL INTEGRATION CENTER. Free trade agreements. [S. 1.]: ARIC, 2016. Available at: < https://aric. adb.org/fta-country > Accessed: March 1, 2016.

BARBOSA JÚNIOR, Ricardo Cesar; COCA, Estevan Leopoldo de Freitas. Conflitos entre o campesinato e o agronegócio no Brasil: os planos-safra 2015-2016. Eutopía: Revista de Desarrollo Económico Territorial, 8, p.13-27, 2015a.

BARBOSA JÚNIOR, Ricardo Cesar; COCA, Estevan Leopoldo de Freitas. The WTO 's international multilateral trade system and its effects on the production and consumption of food. Boletim Meridiano 47, v. 16, n. 150, p.42-49, 2015 b.

BLESH, Jennifer; WITTMAN, Hannah. "Brasilience”: assessing resilience in land reform settlements in the brazilian cerrado. Human Ecology, v. 43, n. 4, p.531-546, 2015.

BURNETT, Kim. The uneasy relationship between international trade and agriculture - synthesis paper. Canadian Food Studies / La Revue canadienne des études sur l'alimentation, v. 2, n. 2, p.107 - 114, 2015.

BURNETT, Kim; MURPHY, S. What place for international trade in food sovereignty? Journal of Peasant Studies, v. 41, n. 6, p.1065 - 1084, 2014.

CLEMENTS, Elizabeth Alice; FERNANDES, Bernardo Mançano. Land grabbing, agribusiness and the peasantry in Brazil and Mozambique. Agrarian South: Journal of Political Economy, v. 2, n. 1, p.41 - 69, 2013.

DESMARAIS, Annette Aurelie. La Vía Campesina: globalization and the power of peasants, Halifax: Fernwood Publishing, 2007.

DESMARAIS, Annette Aurelie. The gift of food sovereignty. Canadian Food Studies, v. 2, n. 2, p.154 - 163, 2015.

FAO Statistical Pocketbook: World Food and Agriculture 2015, Rome: FAO, 2015.

HOPEWELL, Kristen. Different paths to power: the rise of Brazil, India and China at the World Trade Organization. Review of International Political Economy, v. 22, n. 2, p.311 - 338, 2014.

HOPEWELL, Kristen. New Protagonists in Global Economic Governance: Brazilian Agribusiness at the WTO. New Political Economy, v. 18, n. 4, p.603 - 623, 2013.

HURRELL, Andrew; NARLIKAR, Amrita. A new politics of confrontation? Brazil and India in multilateral trade negotiations. Global Society, v. 20, n. 4, p.415 - 433, 2006.

KAUSHIK, P. Is South Korea Ready to Join Trans-Pacific Partnership? The Huffinfton Post - UK. 2015. Available at: <http://www.huffingtonpost.co.uk/preetam-kaushik/is-southkorea-ready-to-j_b_8459246.html> Accessed March 1, 2016. KEOHANE, Robert O; NYE, Joseph. Power and Interdependence: world politics in transition. Boston: Little Brown and company, 1977.

KOREA. Ministry of Foreign Affairs Republic of Korea. FTA Status, 2013. Available at: <http://www.mofa.go.kr/ENG/ policy/fta/status/overview/index.jsp?menu=m_20_80_10>. Accessed March 1, 2016.KRIPKE, Gawain. Food fight: what 
the debate about food security means at the WTO. Canadian Food Studies / La Revue canadienne des études sur l'alimentation, v. 2, n. 2, p.77 - 87, 2015.

MARGULIS, Matias. Multilateral responses to the global food crisis. CAB Reviews: Perspectives in Agriculture, Veterinary Science, Nutrition and Natural Resources, v. 4, n. 12, p.1 10, 2009.

MARGULIS, Matias. The World Trade Organization and Food Security After the Global Food Crises. In D. Drache \& L. Jacobs, eds. Linking Global Trade and Human Rights: New Policy Space in Hard Economic Times. New York: Cambridge University Press, p. 236 - 258, 2014 a.

MARGULIS, Matias. Trading Out of the Global Food Crisis? The World Trade Organization and the Geopolitics of Food Security. Geopolitics, v. 19, n. 2, p.322 - 350, 2014b.

MARGULIS, Matias; MCKEON, Nora; BORRAS JÚNIOR, Saturnino. Land grabbing and global governance: critical perspectives. Globalizations, v. 10, n. 1, p.1 - 23, 2013.

MCMICHAEL, Philip. Land Grabbing as Security Mercantilism in International Relations. Globalizations, v. 10, n. 1, 1, p. $47-64,2013$.

MURPHY, Sophia. Food security and international trade: Risk, trust and rules. Canadian Food Studies / La Revue canadienne des études sur l'alimentation, v. 2, n. 2, p.88 - 96, 2015.

PFRIMER, Matheus Hoffmann; BARBOSA JÚNIOR, Ricardo César. (De)Securitizing collectives of the Brazilian Cerrado and the implementation of an agribusiness complex. Revista NERA, v. 19, n. 30, p.66-87, 2016.

POPKIN, Barry M. Technology, transport, globalization and the nutrition transition food policy. Food Policy, v. 31, n. 6, p.554-569, 2006.

RAKOTOARISOA, Manitra A; IAFRATE, Massimo; PASCHALI, Marianna. Why has Africa become a net food importer? Explaining Africa agricultural and food trade deficits, Rome: FAO, 2012.

SOUZA, Igor Abdalla Medina de. The power of law or the law of power? a critique of the liberal approach to the dispute settlement understanding. Boletim Meridiano 47, v. 16, n. 150, p.34-41, 2015.

WISE, Timothy. Two roads diverged in the food crisis: Global policy takes the one more travelled. Canadian Food Studies / La Revue canadienne des études sur l'alimentation, v. 2, n. 2, p.9-16, 2015.

WITTMAN, Hannah; DESMARAIS, Annette; WIEBE, Nettie (Ed.). Food sovereignty: reconnecting food, nature and community, Halifax, Canada: Food First Books, 2010.

WORLD LAND GRAB. Map. Available at: <http://agro.biodiver.se/wp-content/uploads/2008/11/map21.png> Accessed: March 1, 2016. 